\title{
Kapalı Çıkmalı Betonarme Binaların Deprem Davranışının Değerlendirilmesi
}

\author{
Emrah MERAL* \\ İnşaat Mühendisliği Bölümü, Mühendislik Fakültesi, Osmaniye Korkut Ata Üniversitesi, Osmaniye, Türkiye \\ emrahmeral@osmaniye.edu.tr
}

(Geliș/Received: 29/07/2018;

Kabul/Accepted: 02/07/2019)

\begin{abstract}
Öz: Çalışma kapsamında kapalı çıkmaların betonarme binaların deprem davranışına etkileri doğrusal olmayan zaman tanım alanında analizler yapılarak belirlenmiștir. Bunun için ilk önce hiçbir düzensizliğe sahip olmayan 2-, 4- ve 7- katlı 3-B referans binalar 2007 Deprem Yönetmeliği’ne göre tasarlanmıştır. Daha sonra bu binalara çıkmalar eklenerek kirişli ve kirişsiz kapalı çıkmalı bina modelleri oluşturulmuştur. Binaların 10 adet deprem ivme kaydıyla toplamda 90 adet doğrusal olmayan analizi yapılarak taban kesme kuvveti, tepe noktası ötelenme ve maksimum göreli kat ötelenme oranı gibi parametreler elde edilmiştir. Bu parametreler kapalı çıkmalı binaların deprem davranışının incelenmesi amacıyla karşılaştırılmıştır. Kirişsiz kapalı çıkmalı binalarda diğer binalara göre taban kesme kuvveti taleplerinin düşük, deplasman taleplerinin ise yüksek olduğu belirlenmiștir.
\end{abstract}

Anahtar kelimeler: Betonarme binalar, kapalı çıkma, zaman tanım alanında analiz, doğrusal olmayan davranış.

\section{Evaluation of Earthquake Behavior of Reinforced Concrete Buildings with Heavy Overhang}

Abstract: In the scope of the study, the effects of heavy overhangs on earthquake behavior of reinforced concrete buildings are determined by creating nonlinear time history analyzes. For this at first, 2-, 4- and 7-storey 3-D reference buildings which have no irregularity are designed according to the 2007 Turkish Earthquake Code. Later, extensions are added to these buildings to create beamed and non-beam building models with heavy overhang. A total of 90 nonlinear analyzes of the buildings with 10 earthquake acceleration records are performed to obtain parameters such as base shear force, roof drift and maximum interstory drift ratio. These parameters have been compared to examine earthquake behavior of buildings with heavy overhang. It has been determined that the base shear force demands of the non-beam buildings with heavy overhang are low while the displacement demands of them are high compared to other buildings.

Key words: Reinforced concrete buildings, heavy overhang, time history analysis, nonlinear behavior.

\section{Giriş}

Ülkemizdeki çoğu yapıda zemin katın üstündeki katlarda kat alanını arttırmak için yapılan kapalı çıkmayla ilgili imar mevzuatında çeşitli şartlar bulunmaktadır. Fakat daha önceki çalışmalarda kapalı çıkmaların binaya olumsuz etkilerinin olduğu belirtildiği halde imar mevzuatında ve diğer yönetmeliklerde kapalı çıkmanın yapısal bir düzensizlik olarak geçmemesi düşündürücüdür [1-6]. Bundan dolayıdır ki kapalı çıkmaların günümüzde binalarda yapımına halen devam edilmektedir. Kapalı çıkmalar binanın bir veya birden fazla etrafında çıkıntılar yapılmak suretiyle oluşturulurlar. Tavanda kirişlerin bulunmasının estetik olarak görünümü olumsuz etkilemesinden ve mimari ihtiyaçlardan dolayı kapalı çıkmaların bulunduğu bölgelerde çoğunlukla kirişler inşa edilmeyerek kolon-kiriş arasında bağlantının eksikliğine yol açılır. Kiriş eksiklikleri çerçeve süreksizliğine sebep olduğundan kolon-kiriş arasındaki yük aktarım mekanizması bundan olumsuz olarak etkilenmektedir $[7,8]$. Özellikle tek tarafta yapılan kapalı çıkmaların yapının ağırlık ile rijitlik merkezleri arasındaki mesafeyi artırdığı, ağırlık artışının yapının deprem davranışını etkilediği araştırmacılar tarafından belirtilmiştir $[9,10]$. Ağır kapalı çıkmalara sahip binaların son depremler sırasında yükseklik boyunca düzenli olan binalara göre daha fazla hasar aldığı anlaşılmıştır [11, 12]. Ayrıca depremlerin düssey ivmelerinden dolayı kolonlarla desteklenmeyen kapalı çıkmaların bulunduğu kısımda hasarın oluşması muhtemeldir [10]. Yapılan hasar görebilirlik çalışmalarında yumuşak kat, kısa kolon, çekiçleme, yapısal düzensizlik ve bina yüksekliği gibi parametrelerin yanı sıra ağır kapalı çıkmaların da varlığının önemli bir yere sahip olduğu belirtilmiştir [13-15].

Çalışmanın amacı kapalı çıkmaların düşük ve orta katlı betonarme binaların sismik davranışı üzerindeki etkilerinin doğrusal elastik olmayan zaman tanım alanında analiz ile belirlenmesidir. Bu amaç için düşük ve orta katlı mevcut betonarme binalar yapısal düzensizliği bulunmayan 2-, 4- ve 7- kata sahip referans binalarla temsil

\footnotetext{
* Sorumlu yazar: emrahmeral@ osmaniye.edu.tr. Yazarın ORCID Numarası: 0000-0002-7635-0432
} 
edilmiştir. Daha sonra bu binalara kapalı çıkmalar eklenerek çıkmaların olduğu kısımda kolonlar arasında kirişlerin bulunduğu ve bulunmadığı halleri ile referans binalar karşılaştırılarak değerlendirilmiştir.

\section{Materyal ve Metot}

\subsection{Binaların model özelliklerinin tanımlanması}

Mevcut betonarme yapı stokunun çoğunluğunu oluşturan düşük ve orta katlı yapılar 2-, 4- ve 7- kata sahip bina modelleri tasarlanarak yansıtılmıştır. Bina modellerinin tasarımı 2007 Deprem Yönetmeliği (DBYBHY 2007) prensipleri dikkate alınarak yapılmıştır [16]. Binaların kalıp planlarına ait görünümler Şekil 1a, 1b ve 1c'de verilmiştir. Düzgün ve simetrik geometriye sahip kalıp planları kullanılarak çeşitli çalışmalar yapılmıştır [3, 17 19]. Yapı modellerinin süneklik düzeyi yüksek, Z3 zemin sınıfı üzerinde ve birinci derece deprem bölgesinde olduğu varsayılmıştır. Taşıyıcı sistem, modellerin $\mathrm{X}$ ve $\mathrm{Y}$ doğrultularında perdenin olmadığı deprem yüklerinin sadece çerçevelerle taşındığı binalar olarak ele alınmıştır. Beton basınç dayanımı için $25 \mathrm{MPa}$, boyuna ve enine donatılarının dayanımları için $420 \mathrm{MPa}$ alınarak binalar tasarlanmıştır. Her bir bina modeli için kiriş ve kolon sarılma bölgelerinde $100 \mathrm{~mm}$ aralığında $8 \mathrm{~mm}$ çapında $(\phi 8)$ sadece tek etriyeden oluşan ve çirozun bulunmadı $\breve{g}_{1}$ enine donatı durumu dikkate alınmıştır. Yapıların modellenmesinde ve analizlerinde SAP2000 programı kullanılmıştır [20]. Çalışmada referans (REF) olarak isimlendirilen hiçbir yapısal düzensizliği bulunmayan binalar konut olarak tasarlanmıştır. Referans modellere Y doğrultusunda $1.5 \mathrm{~m}$ genişliğinde tek tarafta kapalı çıkmalar eklenerek çıkmaların olduğu bölgede kolonların kirişlerle bağlı olduğu (KCB) ve olmadığı (KC0) bina modelleri oluşturulmuştur. Çalışmada duvarların ağırlıkları hesaplara dâhil edilmiş olup yatay dayanıma katkısı göz önüne alınmamıştır. Döşemeler tasarımda oluşturulmamış, ağırlıkları ve gelen yükler ilgili döşemelerin etrafındaki kirişlere yayılı yük olarak aktarılmıştır. Rijit diyaframlar her kat seviyesinde uygulanmıştır. Kolon ve kiriş boyutları, 2007 Deprem Yönetmeliği'nde belirtilen minimum kesit şartlarını sağlayacak şekilde seçilmiştir. Tüm kolon ve kirişlerin boyuna donatı miktarı kullanılan kesitlerin \%1'i civarında alınmıştır. Depremin tersinir etkisinden dolayı kirişlerin mesnet bölgelerinde çekme ve basınç bölgeleri yer değiştirebileceğinden kirişlerin alt ve üst kesitlerinde simetrik boyuna donatı kullanılması yoluna gidilerek çekme ve basınç donatısı oranları eşit miktarda seçilmiştir. Doğrusal olmayan yapı davranışı elemanlara atanan plastik mafsallar yoluyla modellere yansıtılmıştır. Plastik mafsalın kuvvet-deformasyon ilişkisini göstermek adına Şekil 2'de verildiği gibi A, B, C, D ve E sınırları tanımlanmıştır [16]. Bu sınırlar için eksenel yük miktarı, malzeme durumu, eleman özellikleri, boyuna ve yanal donatı durumu göz önüne alınmıştır. Moment mafsallarının yanında, kolonlara kesme ve eksenel yük mafsalları, kirişlere ise kesme mafsalları atanmıştır. Doğrusal olmayan bina modellerinin oluşturulması için 2-, 4- ve 7- katlı binalarda sırasıyla 670, 1340 ve 2345 plastik mafsal kullanılmıştır. Plastik mafsal boyu kesit yüksekliğinin yarısı olarak alınmıştır [16]. Beton modeli olarak 2007 Deprem Yönetmeliği'nde önerilen Mander sargılı beton modeli dikkate alınmıştır [21]. Plastik mafsalların tanımlanması ve SAP2000 programına aktarımında SEMAp programı kullanılmıştır [22]. Doğrusal elastik olmayan zaman tanım alanındaki analizlerde Newmark yöntemi göz önüne alınmıştır.

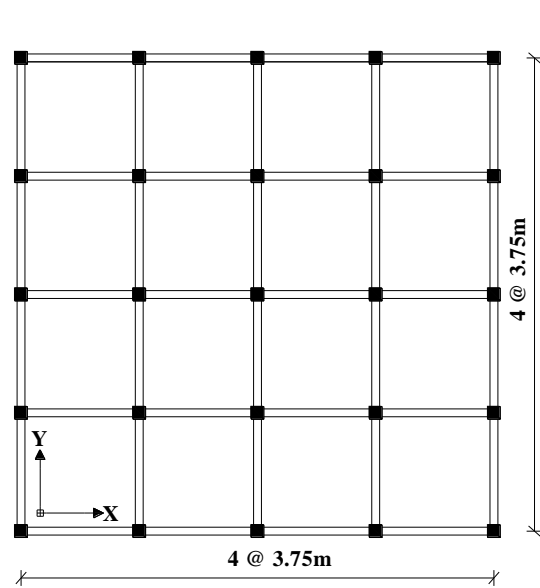

a) Referans bina

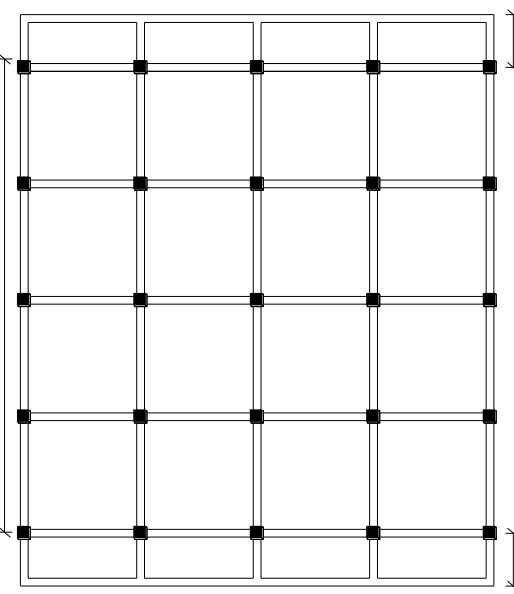

b) Kirişli kapalı çıkmalı bina

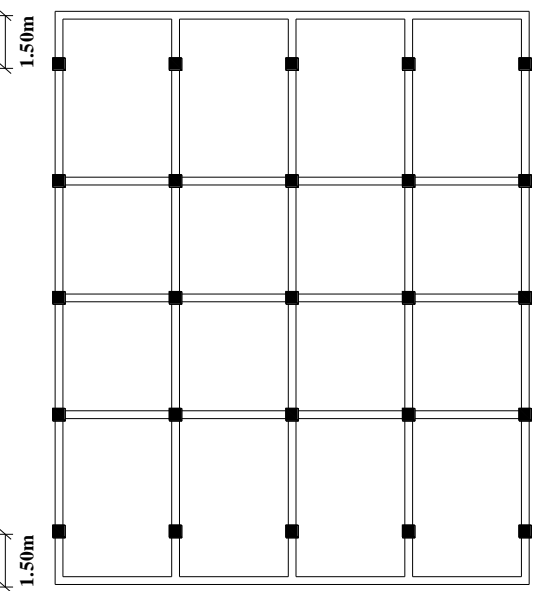

c) Kirişsiz kapalı çıkmalı bina

Şekil 1. Referans ve kapalı çıkmalı binaların kalıp planları. 


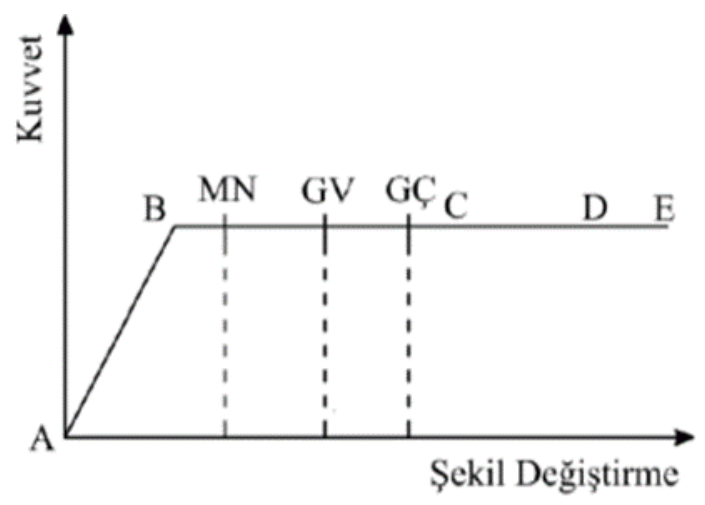

Şekil 2. Plastik mafsala ait kuvvet-şekil değiştirme ilişkisi.

Çalışmada kapsamında kullanılan bina modellerine ait yapısal bilgiler Tablo 1'de gösterilmiştir. Eğilme etkisindeki betonarme yapı elemanlarına ait çatlamış kesit etkin eğilme rijitlikleri (EI)e göz önünde bulundurulmuştur [16]. Bina modellerinde etkin eğilme rijitlik değerleri, kirişlerde 0.4EI, kolonlarda eksenel yükün durumuyla bağlantılı olarak 0.4EI ile 0.8EI arasında kullanılmıştır.

Tablo 1. Binalara ait tanımlayıcı bilgiler.

\begin{tabular}{|c|c|c|c|}
\hline Parametre & 2-katlı yapı & 4-katlı yapı & 7-katlı yapı \\
\hline Yapı Yüksekliği (m) & 5.6 & 11.2 & 19.6 \\
\hline Kiriş Boyutları (mm) & $250 \times 500$ & $250 \times 500$ & $250 \times 600$ \\
\hline Kolon Boyutları(mm) & $400 \times 400$ & $450 \times 450$ & $500 \times 500$ \\
\hline Period (s) & $0.26-0.32$ & $0.48-0.61$ & $0.69-0.88$ \\
\hline Yapı Ă̆ırlığı (kN) & $4479-5330$ & $9953-11861$ & $19159-22845$ \\
\hline
\end{tabular}

\section{2 İvme kayıtlarına ait özellikler}

Doğrusal olmayan zaman tanım alanında yapılan analizlerde kullanılan ivme kayıtları gerçek depremlerden alınan farklı özelliklerdeki kayıtlardır. Seçilen deprem kayıtları Peer web sitesinden (http://peer.berkeley.edu) elde edilmiştir [23]. Deprem ivme kayıtları alınırken, maksimum yer ivmesi değerlerinin (PGA) çeşitli olmasına çalışılmıştır. Aynı zamanda seçilen verilerin, en büyük ve en küçük değerleri arasında farkın çok olmaması için çaba harcanmıştır. Çalışmada kullanılan depremler ve bu depremlere ait ivme kayıtlarının özellikleri Tablo 2'de gösterilmiştir.

Tablo 2. Çalışma kapsamında analizlerde alınan ivme kayıtlarına ait bilgiler.

\begin{tabular}{|c|c|c|c|c|c|c|c|c|}
\hline No & Depremin Adı & Tarih & İstasyon & Bileşen & $\begin{array}{c}\text { PGA } \\
(\mathbf{g})\end{array}$ & $\begin{array}{c}\text { PGV } \\
(\mathbf{c m} / \mathbf{s})\end{array}$ & $\begin{array}{c}\text { Vs30 } \\
(\mathbf{m} / \mathbf{s})\end{array}$ & $\begin{array}{c}\text { Deprem } \\
\text { Süresi } \\
(\mathbf{s})\end{array}$ \\
\hline 1 & Imperial Valley & 15.10 .1979 & El C.Array \#5 & 140 & 0.52 & 46.9 & 206 & 15 \\
\hline 2 & Kocaeli & 17.08 .1999 & Duzce & 180 & 0.31 & 58.8 & 276 & 20 \\
\hline 3 & Landers & 28.06 .1992 & Yermo Fire St. & 360 & 0.15 & 29.7 & 354 & 40 \\
\hline 4 & Loma Pri. & 18.10 .1989 & G.Array \#3 & 90 & 0.37 & 44.7 & 350 & 20 \\
\hline 5 & Northridge & 17.01 .1994 & Canoga Park & 196 & 0.42 & 60.8 & 268 & 20 \\
\hline 6 & Northridge & 17.01 .1994 & Tarzana & 360 & 1.78 & 113.6 & 257 & 20 \\
\hline 7 & Northridge & 17.01 .1994 & Hollyw. W.A & 180 & 0.25 & 33.5 & 235 & 20 \\
\hline 8 & North Palm Springs & 08.07 .1986 & N. Palm Sp. & 210 & 0.59 & 73.3 & 345 & 15 \\
\hline 9 & Spitak & 07.12 .1988 & Gukasian & 0 & 0.20 & 28.6 & 275 & 20 \\
\hline 10 & Whittier Narrows & 01.10 .1987 & Santa Fe Spr. & 48 & 0.43 & 38.1 & 309 & 15 \\
\hline
\end{tabular}


Depremlerin ivme spektrum değerleri, 10 ivme kaydına ait ortalama değerler ile 2007 Deprem Yönetmeliği'nde aşılma olasılığı 50 yılda \%10 olan deprem için Z3 sınıfı zeminindeki tasarım spektrum değerleri Şekil 3'te görülmektedir. Spektrum değerleri oldukça geniş bir bant aralığında dağılım gösterirken, bina periyotlarının 0.26-0.88 saniye aralığında olduğu göz önünde bulundurulduğunda 10 ivme kaydının ortalaması yönetmelik spektrumunun biraz altında kalmaktadır. Çalışmada dikkate alınan 3-B referans ve kapalı çıkmalı bina modellerinin ölçeklendirilmemiş olarak seçilen ivme kayıtlarıyla zaman tanım alanında doğrusal olmayan analizleri yapılarak sismik talepler bulunmuştur.

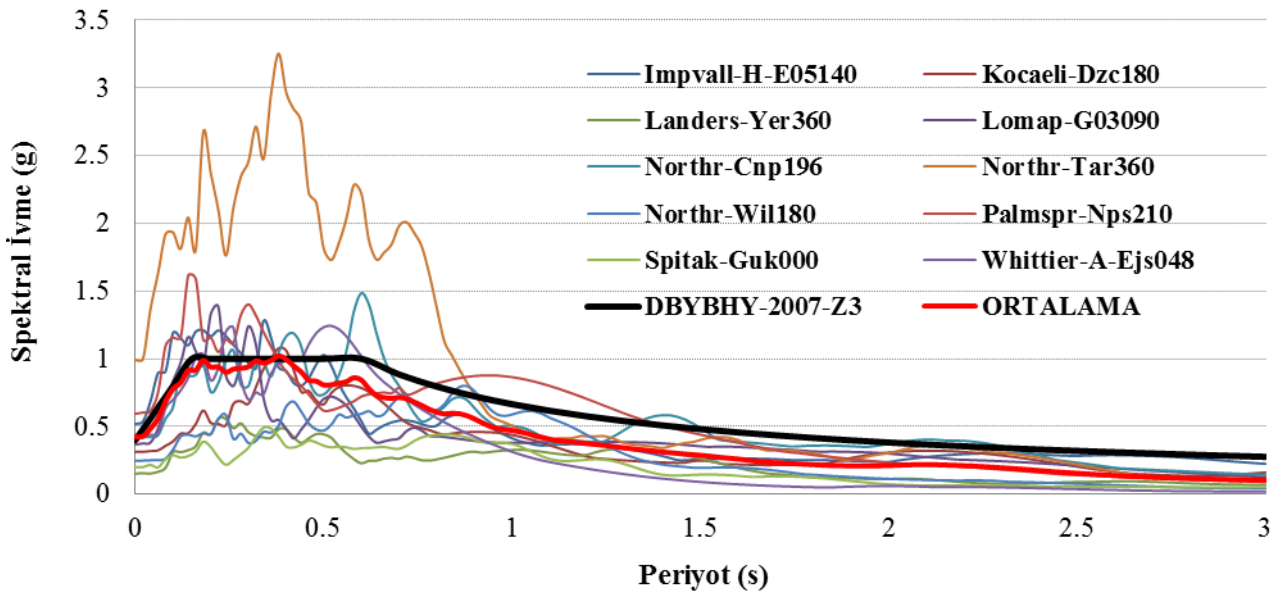

Şekil 3. Depremlerin ivme kayıtlarına ait tepki spektrumları.

\section{Sonuçlar}

Referans (REF) binaların her iki yönde simetrik olması ve kirişli kapalı çıkmalı (KCB) binalarda çıkma bölgesinde X yönündeki kirişlerin kaldırılarak kirişsiz kapalı çıkmalı (KC0) bina modellerinin oluşturulmasından dolayı analizler binaların X yönü dikkate alınarak yapılmıştır. Toplamda 90 adet 3-B doğrusal elastik olmayan dinamik analiz sonucunda binalara ait taban kesme kuvveti, tepe noktası ve maksimum göreli kat deplasmanı parametreleri hesaplanmıştır. Analizlerden bulunan sonuçlara göre, modellerin taban kesme kuvveti, modellerin yatay dayanımıyla eşdeğerdir.

Binalar arasında yapılan kıyaslamaların daha kolay ve anlaşılır olması için analizlerden bulunan taban kesme kuvvetleri binanın ağırlığına oranlanarak "taban kesme kuvveti oranı", tepe noktası deplasmanları bina yüksekliğine oranlanarak "tepe noktası ötelenme oranı” ve göreli kat deplasmanları da kat yüksekliğine bölünerek "göreli kat ötelenme oranı" olarak isimlendirilmiştir. Yapılan analizler sonucunda kirişli (KCB) ve kirişsiz (KC0) kapalı çıkmalı bina modellerinden elde edilen veriler ile referans (REF) bina sonuçları karşılaştırılarak kapalı çıkmanın binalar üzerindeki etkileri araştırılmıştır. Hesaplanan verilerin minimum, maksimum, standart sapma ve ortalama değerleri ile bunların değişimleri istatistiksel olarak incelenmiştir.

Analizlerden elde edilen sonuçlara göre 2-, 4- ve 7- katlı referans ve kapalı çıkmalı bina modellerine ait taban kesme kuvveti oranı değerleri Tablo 3'de gösterilmiştir. Kat sayısı arttıkça ve referans binalardan kirişsiz kapalı çıkmalı binalara doğru gidildikçe taban kesme kuvveti oranlarının azaldığ 1 görülmektedir. Kirişli kapalı çıkmalı binalara ait ortalama taban kesme kuvveti oranları 2-, 4- ve 7- katlı binalarda sirasıyla referans binalarına göre \%6, $\% 4$ ve $\% 8$ civarında düşük hesaplanmıştır. Kirişsiz kapalı çıkmalı binalarda ise bu düşüş \%14, \%19 ve \%23 olmaktadır. Taban kesme kuvveti oranları sonuçlarına bakıldığında kirişli çıkmalı modellerde farklar sınırlı düzeyde kalırken kirişsiz kapalı çıkmalı binalarda kat sayısı arttıkça referans binalar ile farkların açıldığı görülmektedir. Kirişli kapalı çıkmalı binalarda taban kesme kuvveti oranlarının referans binalarına göre düşük olmasını çıkmaların eklenmesinden dolayı oluşan ağırlık artışına bağlayabiliriz. Çıkma bölgesindeki kirişlerin kaldırılması rijitlik azalmasına yol açtığından kirişsiz kapalı çıkmalı binalarda taban kesme kuvveti oranları referans ve kirişli kapalı çıkmalı binalara göre düşük elde edilmiştir. Bulunanlara göre yatay dayanım açısından referans binalarının kirişli ve kirişsiz kapalı çıkmalı binalara göre iyi durumda olduğu açıktır. 
Tablo 3. 2-, 4- ve 7- katlı binalara ait taban kesme kuvveti oranı değerleri.

\begin{tabular}{|lcccccccccc|}
\hline \multirow{2}{*}{\multicolumn{1}{c}{ Depremler }} & \multicolumn{3}{c}{ 2-katlı bina } & \multicolumn{3}{c|}{ 4-katlı bina } & \multicolumn{3}{c|}{ 7-katlı bina } \\
\cline { 2 - 10 } & REF & KCB & KC0 & REF & KCB & KC0 & REF & KCB & KC0 \\
\cline { 2 - 10 } Impvall-H-E05140 & 0.66 & 0.62 & 0.55 & 0.35 & 0.31 & 0.26 & 0.25 & 0.22 & 0.20 \\
Kocaeli-Dzc180 & 0.59 & 0.54 & 0.50 & 0.32 & 0.31 & 0.27 & 0.23 & 0.20 & 0.18 \\
Landers-Yer360 & 0.44 & 0.48 & 0.34 & 0.26 & 0.23 & 0.18 & 0.21 & 0.18 & 0.15 \\
Lomap-G03090 & 0.60 & 0.56 & 0.47 & 0.33 & 0.31 & 0.25 & 0.25 & 0.23 & 0.19 \\
Northr-Cnp196 & 0.70 & 0.59 & 0.59 & 0.37 & 0.35 & 0.29 & 0.24 & 0.23 & 0.19 \\
Northr-Tar360 & 0.77 & 0.69 & 0.66 & 0.37 & 0.43 & 0.34 & 0.29 & 0.26 & 0.23 \\
Northr-Wil180 & 0.37 & 0.40 & 0.34 & 0.32 & 0.29 & 0.26 & 0.25 & 0.23 & 0.17 \\
Palmspr-Nps210 & 0.68 & 0.63 & 0.54 & 0.36 & 0.35 & 0.31 & 0.28 & 0.28 & 0.25 \\
Spitak-Guk000 & 0.24 & 0.27 & 0.38 & 0.26 & 0.24 & 0.23 & 0.21 & 0.20 & 0.15 \\
Whittier-A-Ejs048 & 0.63 & 0.55 & 0.48 & 0.36 & 0.34 & 0.29 & 0.25 & 0.23 & 0.17 \\
\hline Maksimum & 0.77 & 0.69 & 0.66 & 0.37 & 0.43 & 0.34 & 0.29 & 0.28 & 0.25 \\
Minimum & 0.24 & 0.27 & 0.34 & 0.26 & 0.23 & 0.18 & 0.21 & 0.18 & 0.15 \\
Standart Sapma & 0.17 & 0.12 & 0.11 & 0.04 & 0.06 & 0.05 & 0.03 & 0.03 & 0.03 \\
Ortalama & 0.57 & 0.53 & 0.49 & 0.33 & 0.32 & 0.27 & 0.25 & 0.22 & 0.19 \\
\hline
\end{tabular}

Özellikle 2-katlı binaların periyotlarına (0.26-0.32s.) karşılık gelen Northr-Wil180 ve Spitak-Guk000 kayıtlarının küçük spektral ivme değerlerinden dolayı diğer kayıtlara göre daha düşük ve Northr-Tar360 kaydının daha büyük taban kesme kuvveti talebi oluşturması Şekil 4'ten de anlaşılacağı üzere 4- ve 7- katlı binalara göre taban kesme kuvveti oranlarının daha geniş bir bant aralığında yayılmasına sebep olmuştur. Ayrıca düşük yükseklikte olan 2- katlı binaların yatay dayanımlarının 4- ve 7- katlı binalara kıyasla fazla olması da talep farklılığının saçılımını etkilemektedir.

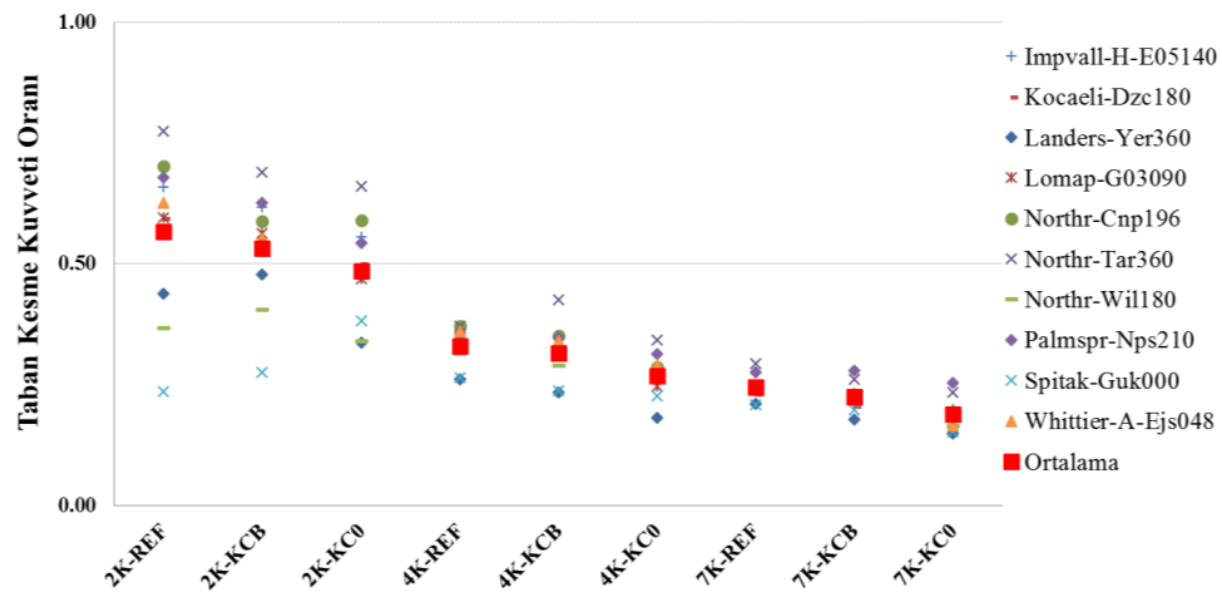

Şekil 4. Referans (REF) binalarına ve kapalı çıkmaya sahip (KCB-KC0) binalara ait taban kesme kuvveti oranlar1.

Analiz sonuçlarına göre 2-, 4- ve 7- katlı referans ve kapalı çıkmalı bina modellerine ait tepe noktası ötelenme oranı değerleri Tablo 4'de verilmiştir. Kirişli kapalı çıkmalı binalarda çıkmaların eklenmesiyle oluşan ağırlık artışı ve kirişsiz kapalı çıkmalı binalarda çıkma bölgesindeki kirişlerin kaldırılmasıyla oluşan rijitlik azalışı, kapalı çıkmalı binaların periyodunu referans binalara göre artırdığından deplasman taleplerinin artmasına sebep olmaktadır [8]. Kirişli kapalı çıkmalı binaların ortalama tepe noktası ötelenme oranları 2- katlı referans binaya göre pek bir değişim göstermezken, 4- ve 7- katlı referans binalarına göre sırasıyla \%14 ve \%8 dolayında fazla bulunmuştur. Kirişsiz kapalı çıkmalı binalarda ise bu artış \%21, \%42 ve \%32 olarak hesaplanmıştır. Kirişsiz çıkmalı modellerin tepe noktası deplasman taleplerinin kirişli modellere göre daha fazla olduğu ve hem kirişli hem 
kirişsiz modellerde kat sayısı arttıkça kapalı çıkmalı modeller ile referans binalar arasındaki farkın azaldığı tespit edilmiştir. Genel olarak ortalama tepe noktası ötelenme değerlerine bakıldığında 4- katlı tüm bina gruplarında 2ve 7- katlı binalara göre daha yüksek deplasman talepleri elde edilmiştir. Bu durum 4- katlı binaların periyot aralıklarında (0.48-0.61s.) seçilen depremlerin ivme kayıtlarının tepki spektrumlarında yüksek spektral ivme değerleri almasından dolayı deplasman taleplerini artırmasıyla açıklanabilir. Benzer şekilde özellikle orta katlı binalarda diğer katlı binalara göre deplasman taleplerinin fazla bulunduğu çalışmalar mevcuttur [8, 24].

Tablo 4. 2-, 4- ve 7- katlı binalara ait tepe noktası ötelenme oranı değerleri (\%).

\begin{tabular}{|lcccccccccc|}
\hline \multirow{2}{*}{\multicolumn{1}{c}{ Depremler }} & \multicolumn{3}{c}{ 2-katlı bina } & \multicolumn{3}{c|}{ 4-katl1 bina } & \multicolumn{3}{c|}{ 7-katlı bina } \\
\cline { 2 - 10 } Impvall-H-E05140 & REF & KCB & KC0 & REF & KCB & KC0 & REF & KCB & KC0 \\
\cline { 2 - 10 } Kocaeli-Dzc180 & 0.44 & 0.47 & 0.53 & 0.45 & 0.52 & 0.58 & 0.30 & 0.37 & 0.51 \\
Landers-Yer360 & 0.25 & 0.28 & 0.41 & 0.36 & 0.42 & 0.67 & 0.39 & 0.40 & 0.42 \\
Lomap-G03090 & 0.18 & 0.23 & 0.24 & 0.27 & 0.28 & 0.24 & 0.21 & 0.26 & 0.28 \\
Northr-Cnp196 & 0.29 & 0.36 & 0.41 & 0.38 & 0.38 & 0.45 & 0.35 & 0.41 & 0.61 \\
Northr-Tar360 & 1.52 & 0.36 & 0.72 & 0.84 & 0.80 & 0.95 & 0.42 & 0.41 & 0.58 \\
Northr-Wil180 & 0.15 & 0.19 & 0.23 & 0.35 & 0.40 & 0.63 & 0.43 & 0.45 & 0.48 \\
Palmspr-Nps210 & 0.53 & 0.64 & 0.67 & 0.58 & 0.74 & 1.17 & 0.74 & 0.85 & 1.04 \\
Spitak-Guk000 & 0.09 & 0.13 & 0.24 & 0.25 & 0.27 & 0.35 & 0.24 & 0.26 & 0.38 \\
Whittier-A-Ejs048 & 0.36 & 0.32 & 0.35 & 0.55 & 0.58 & 0.73 & 0.37 & 0.38 & 0.42 \\
\hline Maksimum & 1.52 & 1.35 & 1.34 & 0.84 & 1.15 & 1.17 & 0.90 & 0.89 & 1.04 \\
Minimum & 0.09 & 0.13 & 0.23 & 0.25 & 0.27 & 0.24 & 0.21 & 0.26 & 0.28 \\
Standart Sapma & 0.41 & 0.35 & 0.34 & 0.21 & 0.27 & 0.32 & 0.22 & 0.22 & 0.26 \\
Ortalama & 0.43 & 0.43 & 0.51 & 0.49 & 0.56 & 0.69 & 0.44 & 0.47 & 0.58 \\
\hline
\end{tabular}

Tepe noktası ötelenme oranlarına bakıldığında, Northr-Tar360 deprem ivme kaydının tüm binalarda yüksek deplasman talepleri oluşturduğu Şekil 5 'te görülmektedir. Buna karşın Spitak-Guk000 deprem ivme kaydının 2ve 4- katlı binalarda, Landers-Yer360 deprem ivme kaydının 7- katlı binalarda düşük deplasman taleplerinin oluşmasına sebep olduğu açıkça gözükmektedir. Binalardaki bu talep farklılığı dikkate alınan binaların periyotlarına karşılık gelen deprem ivme kayıtlarının tepki spektrumlarında aldıkları spektral ivme değerleriyle ilişkilendirilebilir. Ayrıca, 4- katlı binaların deplasman taleplerinin değişkenliğinin diğer binalara göre daha fazla olduğu açıktır (Şekil 5).

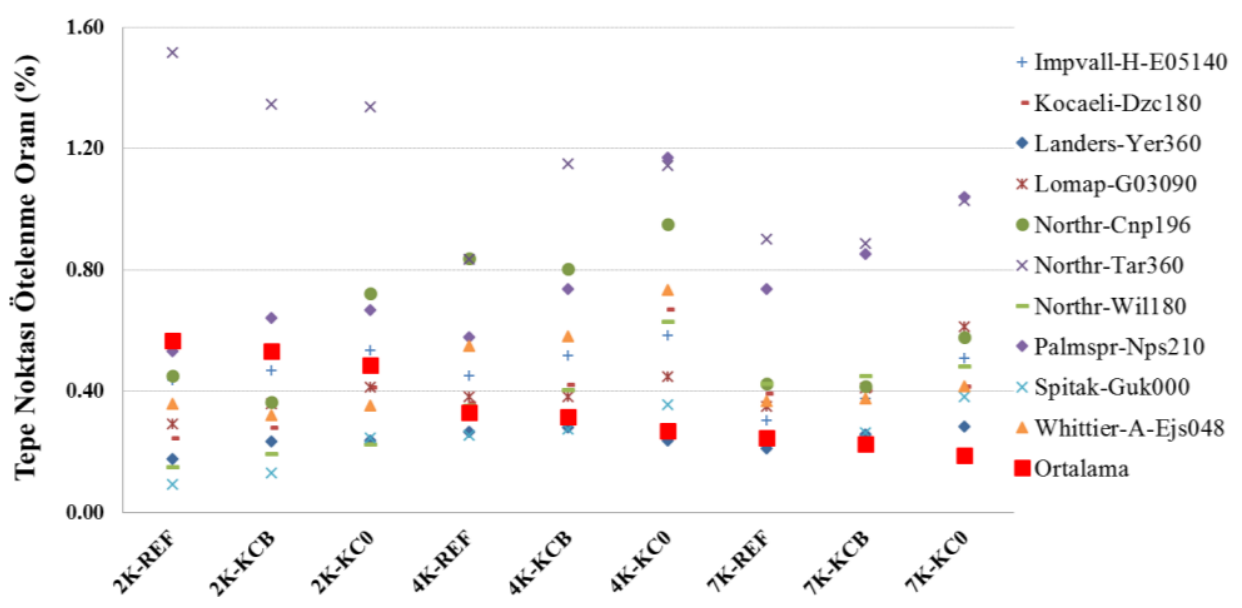

Şekil 5. Referans (REF) binalarına ve kapalı çıkmaya sahip (KCB-KC0) binalara ait tepe noktası ötelenme oranlar1. 
Analizlerden elde edilenlere göre 2-, 4- ve 7- katlı referans ve kapalı çıkmalı bina modellerine ait göreli kat ötelenme oranı değerleri Tablo 5'de görülmektedir. Kirişli kapalı çıkmalı binalara ait göreli kat ötelenme oranları referans bina verilerine bölündügünde bulunan değerler 2- katlı binalarda 0.79-1.38, 4-katlı binalarda 0.97-1.34, 7-katlı binalarda ise 0.93-1.26 arasında değişmektedir. Kirişsiz kapalı çıkmalı binalarda ise bu oranlar 2- katlı binalarda 0.81-2.44, 4-katlı binalarda 0.85-1.81, 7-katlı binalarda ise 0.96-1.58 arasındadır. Kapalı çıkmalı binaların periyodunun referans binalara göre fazla olması bazı ivme kayıtlarının spektral ivme değerlerinin azalmasına sebep olduğundan bu durum kapalı çıkmalı binalarda daha düşük deplasman taleplerinin elde edilmesine yol açmıştır. Göreli kat ötelenme oranlarına ait minimum ve maksimum değerler arasındaki farklar değerlendirildiğinde 2-, 4- ve 7- katlı referans binalar için sırasıyla 18.39, 3.24 ve 4.24 kat olmaktadır. Bu farklar kirişli kapalı çıkmalı binalarda 13.90, 3.99 ve 3.89 kat olurken kirişsiz kapalı çıkmalı binalarda ise 6.81, 4.60 ve 3.97 kat olmaktadır. Minimum ve maksimum göreli kat ötelenme oranı farkları 2- ve 7- katlı binalarda referans binalardan kirişsiz kapalı çıkmalı binalara doğru gidildikçe azalmakta, 4- katlı binalarda ise artma eğilimi göstermektedir.

Tablo 5. 2-, 4- ve 7- katlı binalara ait göreli kat ötelenme oranı değerleri (\%).

\begin{tabular}{|lcccccccccc|}
\hline \multirow{2}{*}{ Depremler } & \multicolumn{3}{c}{ 2-katlı bina } & \multicolumn{3}{c|}{ 4-katlı bina } & \multicolumn{3}{c|}{ 7-katlı bina } \\
\cline { 2 - 11 } & REF & KCB & KC0 & REF & KCB & KC0 & REF & KCB & KC0 \\
\cline { 2 - 11 } Impvall-H-E05140 & 0.54 & 0.60 & 0.64 & 0.74 & 0.81 & 0.85 & 0.60 & 0.75 & 0.83 \\
Kocaeli-Dzc180 & 0.28 & 0.32 & 0.47 & 0.56 & 0.66 & 0.94 & 0.76 & 0.80 & 0.73 \\
Landers-Yer360 & 0.20 & 0.26 & 0.24 & 0.41 & 0.43 & 0.34 & 0.35 & 0.42 & 0.48 \\
Lomap-G03090 & 0.32 & 0.43 & 0.43 & 0.61 & 0.60 & 0.67 & 0.65 & 0.76 & 1.03 \\
Northr-Cnp196 & 0.59 & 0.46 & 0.86 & 1.23 & 1.20 & 1.25 & 0.79 & 0.76 & 0.99 \\
Northr-Tar360 & 1.93 & 2.01 & 1.57 & 1.22 & 1.64 & 1.45 & 1.50 & 1.39 & 1.58 \\
Northr-Wil180 & 0.17 & 0.22 & 0.23 & 0.56 & 0.63 & 0.89 & 0.81 & 0.82 & 0.85 \\
Palmspr-Nps210 & 0.66 & 0.82 & 0.78 & 0.87 & 1.08 & 1.58 & 1.48 & 1.65 & 1.91 \\
Spitak-Guk000 & 0.11 & 0.15 & 0.26 & 0.38 & 0.41 & 0.52 & 0.49 & 0.49 & 0.69 \\
Whittier-A-Ejs048 & 0.40 & 0.35 & 0.37 & 0.84 & 0.84 & 0.97 & 0.71 & 0.72 & 0.79 \\
\hline Maksimum & 1.93 & 2.01 & 1.57 & 1.23 & 1.64 & 1.58 & 1.50 & 1.65 & 1.91 \\
Minimum & 0.11 & 0.15 & 0.23 & 0.38 & 0.41 & 0.34 & 0.35 & 0.42 & 0.48 \\
Standart Sapma & 0.53 & 0.55 & 0.41 & 0.30 & 0.38 & 0.39 & 0.38 & 0.38 & 0.43 \\
Ortalama & 0.52 & 0.56 & 0.58 & 0.74 & 0.83 & 0.95 & 0.81 & 0.86 & 0.99 \\
\hline
\end{tabular}

Şekil 6 incelendiğinde tepe noktası ötelenme oranlarına benzer bir eğilim gözlenmekte olup deprem ivme kayıtlarının farklı göreli ötelenme talepleri oluşturarak bunların ortalama değerlerin etrafında geniş bir aralıkta yayıldı̆̆ı sonucuna ulaşılmaktadır.

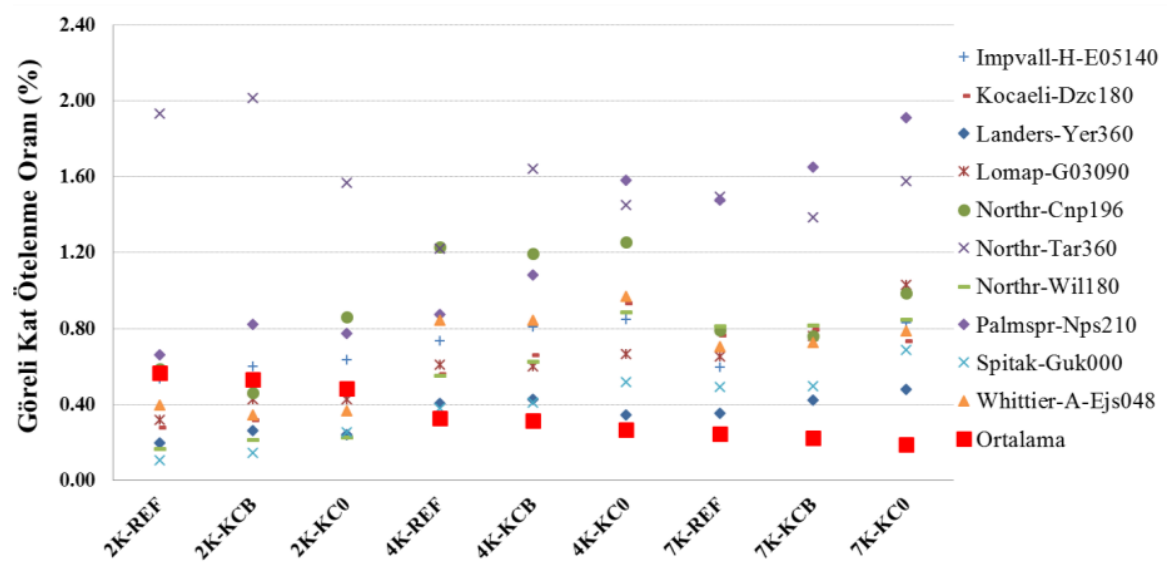

Şekil 6. Referans (REF) binalarına ve kapalı çıkmaya sahip (KCB-KC0) binalara ait göreli kat ötelenme oranlar1. 
Referans ve kapalı çıkmalı binalar için maksimum göreli kat deplasmanının oluştuğu kat belirlenerek bu katın diğer katlara göre olma sıklığı durumu Şekil 7'de verilmiştir. Maksimum göreli kat deplasmanının çoğunluğunun 2- ve 4- katlı binalarda 1. ve 2. katta oluşmasından dolayı çıkmanın varlığının maksimum göreli kat deplasmanının oluştuğu katı etkilediği sonucuna varılamamıştır (Şekil 7). Fakat buna karşın 7- katlı binalarda ise maksimum göreli kat deplasmanının tüm bina gruplarında 2. ve 3. katta oluşmasına rağmen kirişsiz kapalı çıkmalı binalarda az da olsa 3. katta bulunma sıklığının artması kolonların üst katlara doğru eksenel yüklerinin azalmasına bağlı olarak çatlamış kesit rijitliği katsayılarının düşmesinin ve çıkmanın etkisinin sebep olduğu söylenebilir.

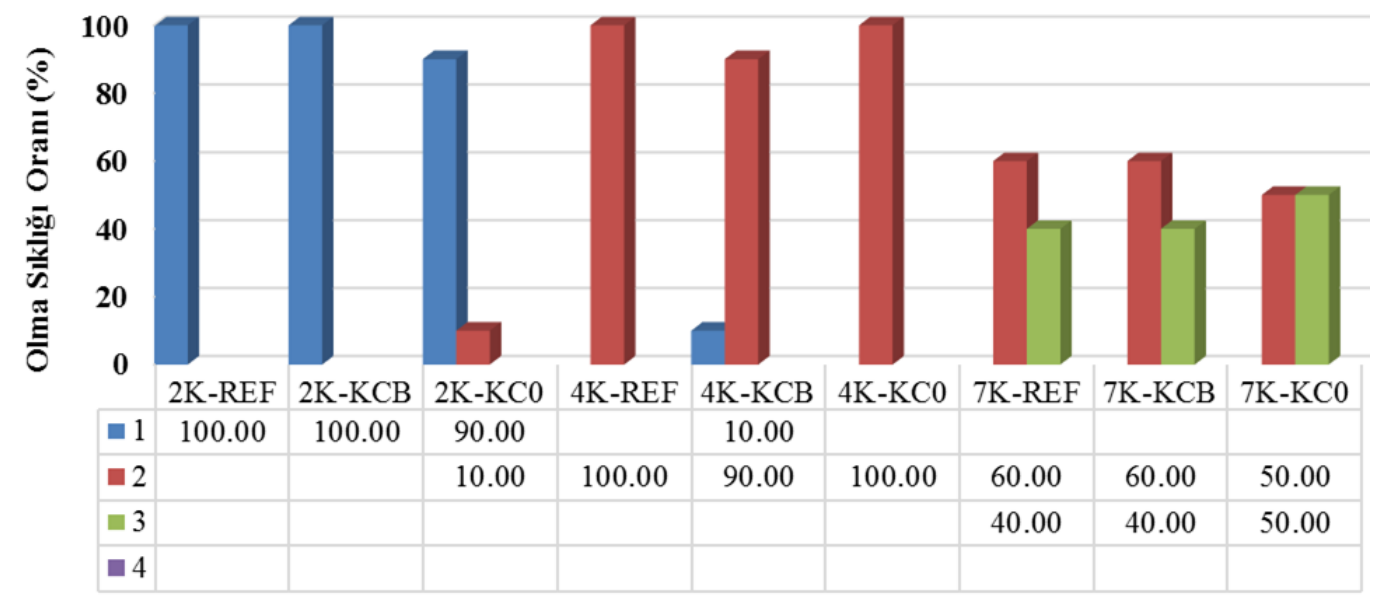

Şekil 7. Referans (REF) binalarında ve kapalı çıkmaya sahip (KCB-KC0) binalarda maksimum göreli kat ötelenmesinin çıktığı kat için olma sıklığı oranı (maksimum göreli kat deplasmanının o katta olma sayısı

/kullanılan ivme kaydı sayıs1).

Northr-Tar360 deprem ivme kaydı için referans ve kapalı çıkmalı binaların orta çerçevelerinde oluşan plastik mafsal dağılımı Şekil 8'de gösterilmiştir. Kirişsiz kapalı çıkmalı binalarda kirişlerde oluşan mafsallaşmanın daha ileri seviyede olduğu ve bunun yanında ayrıca 2-katlı binanın kirişlerindeki mafsal sayısının da diğer bina gruplarına göre daha fazla olduğu sonucuna varılmaktadır. Kolonlardaki mafsallaşma durumuna bakıldığında, tüm 2-katlı binaların her iki katında mafsallaşma görülürken, 4- ve 7- katlı binalarda ise kirişli ve kirişsiz bina modellerin üst katlarında da plastik mafsallar oluşurken referans binalarında sadece alt katta oluşmaktadır.

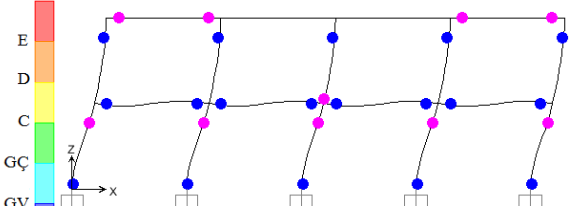

a) $2 \mathrm{~K}-\mathrm{REF}$

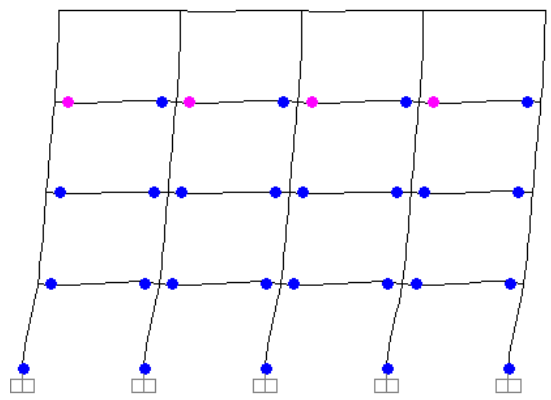

d) $4 \mathrm{~K}-\mathrm{REF}$

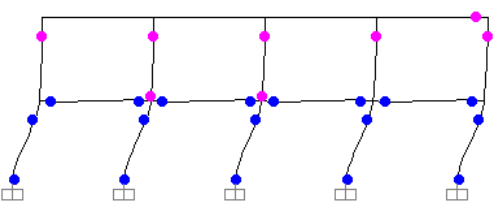

b) $2 \mathrm{~K}-\mathrm{KCB}$

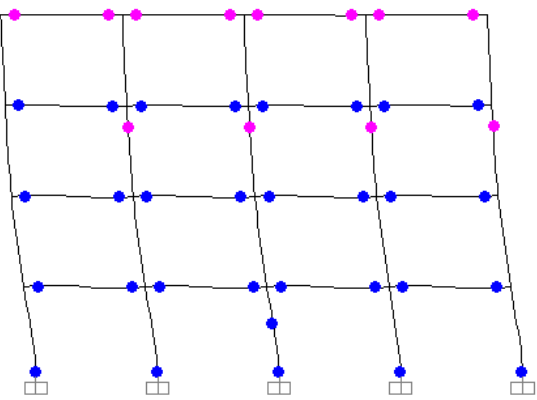

e) $4 \mathrm{~K}-\mathrm{KCB}$

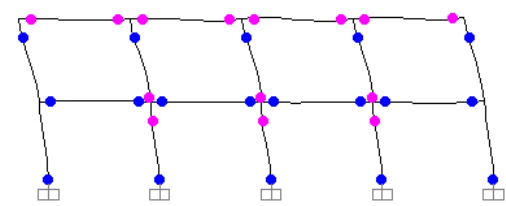

c) $2 \mathrm{~K}-\mathrm{KCO}$

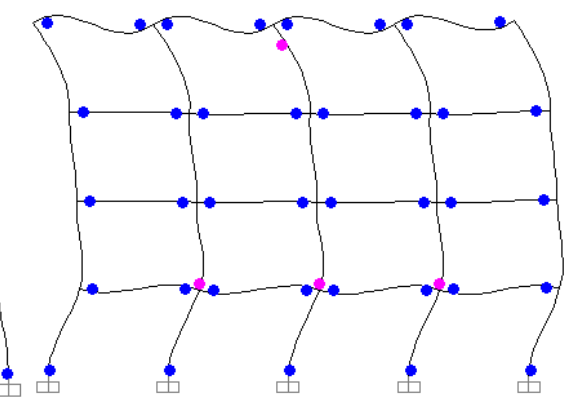

f) $4 \mathrm{~K}-\mathrm{KCO}$ 


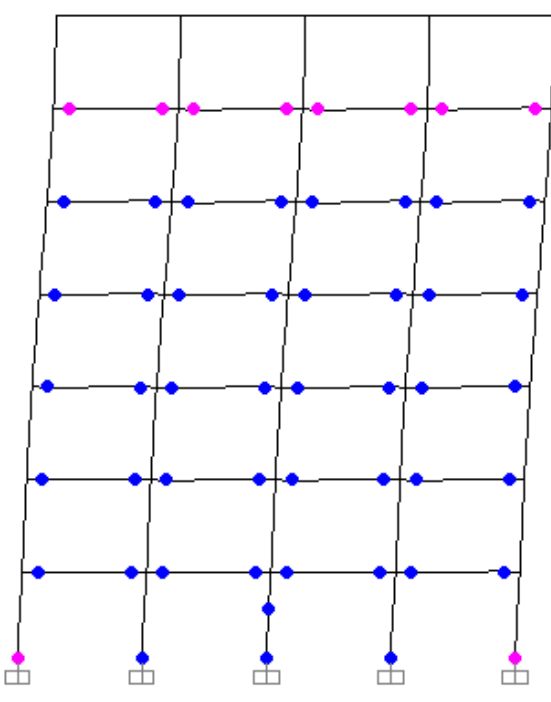

g) $7 \mathrm{~K}-\mathrm{REF}$

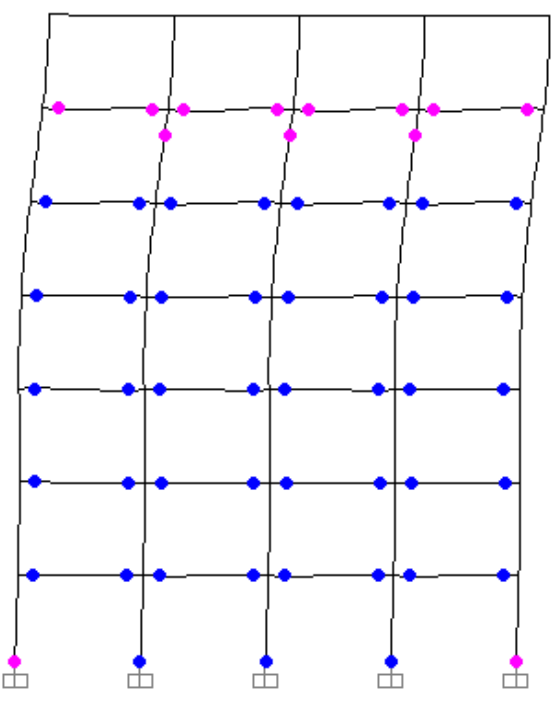

h) $7 \mathrm{~K}-\mathrm{KCB}$

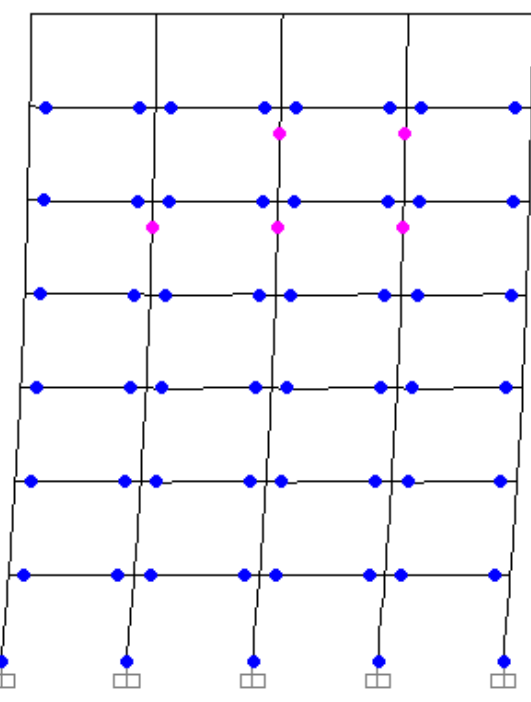

1) $7 \mathrm{~K}-\mathrm{KC} 0$

Şekil 8. Northr-Tar360 deprem ivme kaydına göre binalardaki plastik mafsal dağılımı.

\section{Tartışma}

Düşük ve orta katlı mevcut betonarme yapı stoğunun 2-, 4- ve 7- katlı olarak yansıtıldığı çalışmada kapalı çıkmaların binaların deprem davranışına etkileri doğrusal olmayan zaman tanım alanında analizler yapılarak değerlendirilmiştir. Bu amaçla başlangıçta hiçbir düzensizliğe sahip olmayan düzgün ve simetrik kalıp planına sahip 3-B referans binalar tasarlanmıştır. Daha sonra bu modellere kapalı çıkmalar eklenerek çıkmaların olduğu kısımda kolonların kirişlerle bağlı olduğu ve olmadığı bina modelleri hazırlanmıştır. Binaların sadece X yönü dikkate alınarak 10 adet deprem ivme kaydıyla toplamda 90 adet doğrusal olmayan analiz gerçekleştirilmiştir. Analizler sonucunda bulunan taban kesme kuvveti oranı, tepe noktası ötelenme oranı, maksimum göreli kat ötelenme oranı parametreleri açısından referans binaları ile kapalı çıkmalı binalar karşılaştırılarak çıkmaların etkileri yorumlanmaya çalışılmıştır. Çalışma kapsamında elde edilen bulgular aşağıda özetlenerek açıklanmıştır.

$\checkmark \quad$ Taban kesme kuvveti oranları için ortalama değerler üzerinden yapılan değerlendirmede kirişli kapalı çıkmalı binalarda referans binalarına göre $\% 8$ dolayında sınırlı bir düşüş hesaplanırken kirişsiz kapalı çıkmalı binalarda ise bu en fazla $\% 23$ seviyelerine çıkmıştır.

$\checkmark \quad$ Ortalama tepe noktası ötelenme oranlarına bakıldığında kirişli kapalı çıkmalı binalarda referans binalarına göre \%14 dolayında fazla bulunurken kirişsiz kapalı çıkmalı binalarda ise bu artış en fazla \%42 olmuştur.

$\checkmark \quad$ Kirişli kapalı çıkmalı binalar ile referans binalar arasındaki göreli kat ötelenme oranı farkları 2-, 4- ve 7- katlı binalarda sırasıyla 1.38, 1.34 ve 1.26 kata kadar çıkarken kirişsiz kapalı çıkmalı binalarla olan farklar ise 2.44, 1.81 ve 1.58 kata kadar çıkabilmektedir.

$\checkmark \quad$ Kat sayısı arttıkça genel olarak taban kesme kuvveti açısından kapalı çıkmalı binalar ile referans binalar arasındaki talep farkı artmaktadır. Buna karşın binalar arasındaki deplasman talepleri farkı 2- ve -7 katlı binalara kıyasla 4- katlı binada daha fazla görülmektedir.

$\checkmark \quad$ Kapalı çıkmalı binaların periyodunun referans binalara göre fazla olması birkaç ivme kaydının spektral ivme değerinin düşmesine sebep olduğundan bazı sonuçlar için kapalı çıkmalı binalarda daha düşük deplasman talepleri hesaplanmıştır.

$\checkmark \quad$ Genel olarak kullanılan deprem ivme kayıtlarının kirişsiz kapalı çıkmalı binaları diğer referans binalarına ve kirişli kapalı çıkmalı binalara göre talep açısından daha olumsuz etkilediğini söylemek mümkündür.

\section{Kaynaklar}

[1] Özmen HB, Hızlı değerlendirme yöntemlerinde kullanılan parametrelerin yapı performansı üzerindeki etkilerinin incelenmesi. Yüksek Lisans Tezi, Pamukkale Üniversitesi, Denizli, 2005. 
[2] İnel M, Özmen HB, Bilgin H. Türkiye'de yaşanan deprem hasarları ve yapı stoğunun değerlendirilmesi. Altıncı Ulusal Deprem Mühendisliği Konferans1; 16-20 Ekim 2007; İstanbul.

[3] Inel M, Ozmen HB, Bilgin H. Re-evaluation of building damage during recent earthquakes in Turkey. Engineering Structures 2008; 30(2): 412-427.

[4] Sarı H. Mevcut betonarme yapılardaki tasarım olumsuzluklarının yapı performansına etkisi. Yüksek Lisans Tezi, Sakarya Üniversitesi, Sakarya, 2010.

[5] Çaycı BT, Simav depremi sonrası bina yapısal özellikleri ile hasar seviyesi ilişkisinin araştırılması. Yüksek Lisans Tezi, Pamukkale Üniversitesi, Denizli, 2012.

[6] İnel M, Özmen HB, Çaycı BT. Simav ve Van depremleri (2011) yapı hasar nedenlerinin değerlendirilmesi. Pamukkale Üniversitesi Mühendislik Bilimleri Dergisi 2013; 19(6): 256-265.

[7] İnel M, Bucaklı M, Özmen HB. Betonarme binalarda çerçeve süreksizliğinin yapı performansı üzerindeki etkileri. Uluslararası Sakarya Deprem Sempozyumu; 1-2 Ekim 2009; Sakarya.

[8] Özmen HB, İnel M, Çaycı BT. Kapalı çıkma düzensizliğinin betonarme yapıların sismik davranışına etkilerinin değerlendirilmesi. Yedinci Ulusal Deprem Mühendisliği Konferans1; 30 Mayıs-3 Haziran 2011; İstanbul.

[9] Doğangün A. Performance of reinforced concrete buildings during the May 12003 Bingöl earthquake in Turkey. Engineering Structures 2004; 26(6): 841-856.

[10] Özmen HB, Düşük ve orta yükseklikteki betonarme yapıların deprem performanslarını etkileyen faktörlerin irdelenmesi. Doktora Tezi, Pamukkale Üniversitesi, Denizli, 2011.

[11] Özcebe G. Deprem güvenliğinin saptanması için yöntemler geliştirilmesi. TÜBİTAK İÇTAG YMAÜ İ574 Numaralı Araştırma Projesi Sonuç Raporu, Ankara, 2004.

[12] Sucuoglu H, Yazgan U. Simple survey procedures for seismic risk assessment in urban building stocks. Seismic Assessment and Rehabilitation of Existing Buildings 2003; 29: 97-118.

[13] Srikanth T, Kumar RP, Singh AP, Rastogi BK, Kumar S. Earthquake vulnerability assessment of existing buildings in Gandhidham and Adipur cities Kachchh, Gujarat (India). European Journal of Scientific Research 2010; 41(3): 336-353.

[14] Alam N, Alam MS, Tesfamariam S. Buildings' seismic vulnerability assessment methods: a comparative study. Natural Hazards 2012; 62(2): 405-424.

[15] Ahmed MM, Jahan I, Alam MJ. Earthquake vulnerability assessment of existing buildings in cox's-bazar using field survey \& GIS. International Journal of Engineering Research \& Technology 2014; 3(8): 1147-1156.

[16] DBYBHY 2007. Deprem Bölgelerinde Yapılacak Binalar Hakkında Yönetmelik. Ankara: Bayındırlık ve İskân Bakanlığı, 2007.

[17] Irtem E, Hasgul U. Investigation of effects of nonlinear static analysis procedures to performance evaluation on low-rise RC buildings. Journal of Performance of Constructed Facilities 2009; 23(6): 456-466.

[18] Arslan MH. An evaluation of effective design parameters on earthquake performance of RC buildings using neural networks. Engineering Structures 2010; 32(7): 1888-1898.

[19] Erdem TR. Performance evaluation of reinforced concrete buildings with softer ground floors. Gradevinar 2016; 68(1): 39-49.

[20] SAP2000 V-19. Integrated finite element analysis and design of structures basic analysis reference manual. Berkeley (CA, USA): Computers and Structures Inc., 2017.

[21] Mander JB, Priestley MJN, Park R. Theoretical stress-strain model for confined concrete. Journal of Structural Engineering 1988; 114(8): 1804-1825.

[22] SEMAp. Sarg1 etkisi modelleme analiz programı. Tubitak Proje No: 105M024, 2008.

[23] Peer, 2011. Pacific Earthquake Engineering Research Center, http://peer.berkeley.edu, Erişim tarihi: 25 Temmuz 2018.

[24] İnel M, Özmen HB, Hıra MA. Yumuşak kat düzensizliğinin betonarme yapıların sismik davranışına etkilerinin değerlendirilmesi. Yedinci Ulusal Deprem Mühendisliği Konferans1; 30 Mayıs-3 Haziran 2011; İstanbul. 